\title{
The quern quarry of La Calera (Agaete, Gran Canaria, Spain): Working volcanic tuff with stone tools
}

\section{Yurena Naranjo-Mayor, Amelia Rodríguez-Rodríguez and Isabel Francisco-Ortega}

\begin{abstract}
This paper identifies the operational sequence of volcanic tuff rotary quern production on the Island of Gran Canaria. This is carried out by analysing the tool marks on the face of the La Calera (Agaete) quarry and the abandoned quern roughouts. Stone implements served in all of the stages of quern manufacture as metal tools were unknown in Pre-European Gran Canaria.
\end{abstract}

Keywords: quern quarry, rotary quern, roughout, volcanic tuff, stone pick

Yurena Naranjo-Mayor. G. I. Tarha. Departamento de Ciencias Históricas, Universidad de Las Palmas de Gran Canaria, Plaza de la Constitución s/n 35003, Las Palmas de Gran Canaria (Las Palmas, Spain), yurena.nm@ gmail.com

Amelia Rodríguez-Rodríguez.G.I. Tarha.Departamento de Ciencias Históricas, amelia.rodriguez@ulpgc.es

Isabel Francisco-Ortega. G.I. Sociedades Cazadoras-Recolectoras. Departamento de Prehistoria, antropología e Histoia Antigua, Universidad de La Laguna, ixa@telefonica.net

\section{Introduction and objectives}

Rotary querns on archaeological sites of PreEuropean contexts on the Island of Gran Canaria are common finds, an indication of their importance in daily life. The main purpose of this study is to determine the operational sequence of production of these artefacts at their point of origin: quarries.

Their production at the quarries themselves cannot be dated with precision due to the absence of characteristic finds (such as pottery) In dated contexts such as settlements (Fig. 1), they range between the 6th-7th centuries $\mathrm{AD}$ until the 15th century AD (González et al. 2009; RodríguezRodríguez et al. 2012). Moreover, as noted in studies of traditional domestic tools, the use of rotary querns after the arrival of the Europeans to grind plants and minerals continued well into the 20th century (Rodríguez-Rodríguez 2009).

Rotary querns in the Canary Islands have been the object of several studies (Rafols and Cuscoy
1950; Galván 1998; Rodríguez-Rodríguez and Galindo 2004). Research regarding their production, nonetheless, only began recently. In a first stage the quarries were identified and described. This was followed by studies of provenance, some of which are ongoing (Rodríguez-Rodríguez et al. 2006; Rodríguez-Rodríguez et al. 2007; RodríguezRodríguez et al. 2010; Mangas et al. 2008). Although volcanic tuff (compact lapilli) was not the only rock exploited (Rodríguez-Rodríguez et al. 2004), it is the most common both from the standpoint of quarries and rotary quern finds at settlements (Rodríguez-Rodríguez 2009).

An original aspect of the extraction and fashioning of rotary querns is that the Pre-Hispanic Canarians did not possess metal implements. The tools serving to extract and fashion the rotary querns were therefore of stone, a fact that required adopting specific strategies.

The current study focuses on the quarry of La Calera (Agaete, Gran Canaria), the largest (to date) 
a
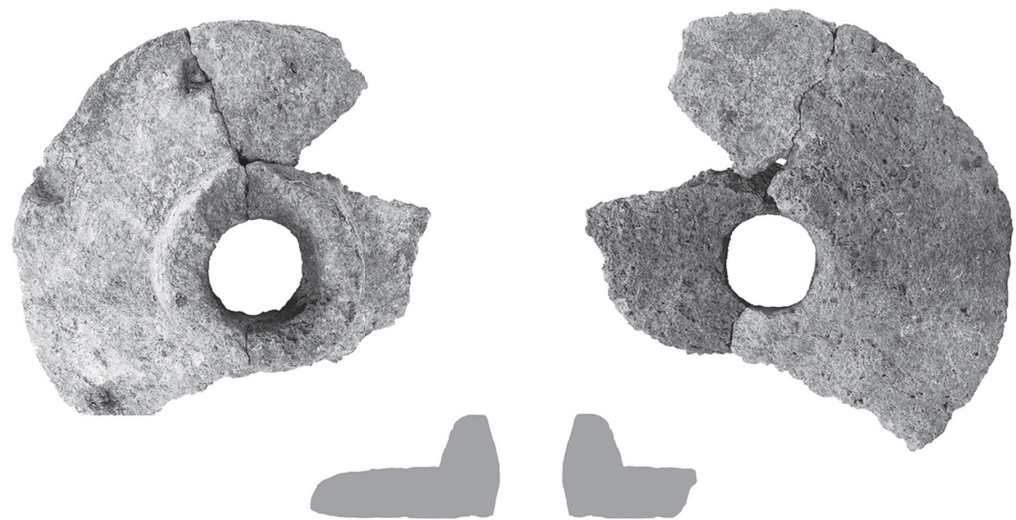

$\mathrm{b}$
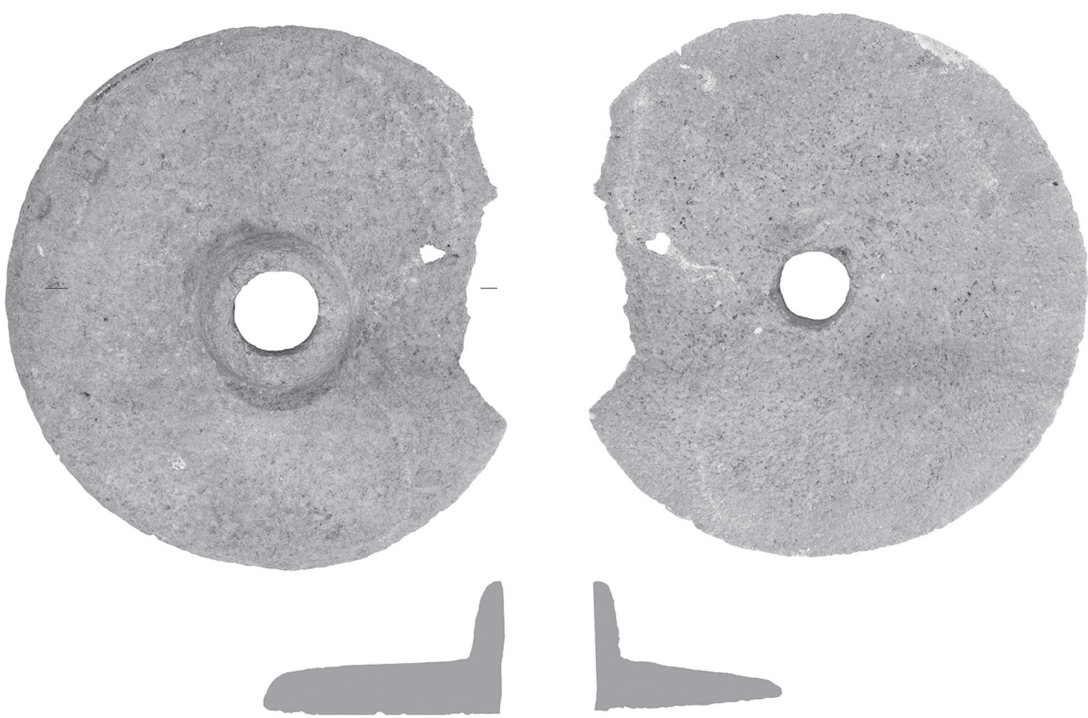

c
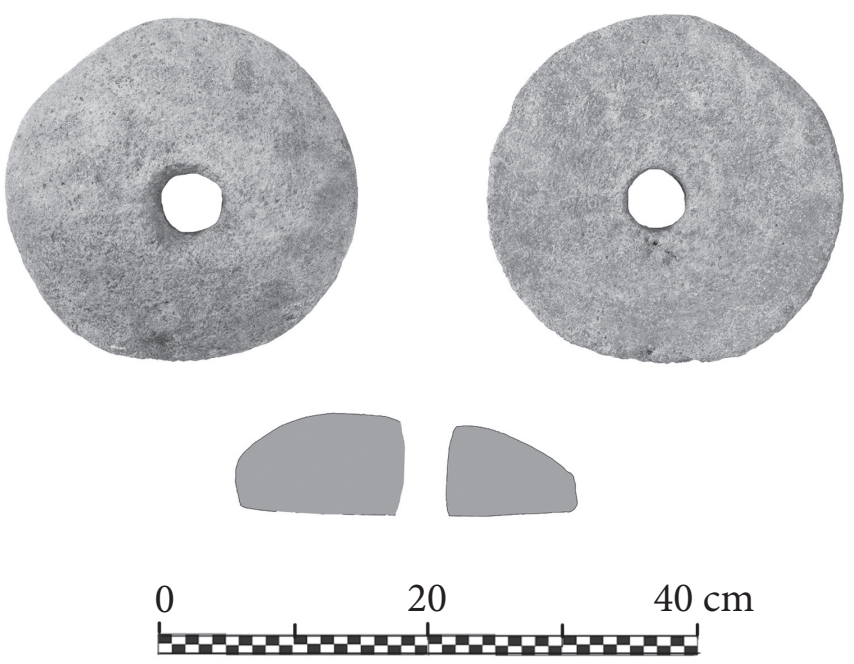

Fig. 1: Examples of volcanic tuff rotary querns from the Island of Gran Canaria. a) Los Barros-Las Palmas de Gran Canaria (ø: $35 \mathrm{~cm}$ ); b) Cenobio de Valerón-Santa María de Guía (ø: $39.7 \mathrm{~cm}$ ); c) Cueva Pintada-Gáldar (ø: $27 \mathrm{~cm}$ ). 


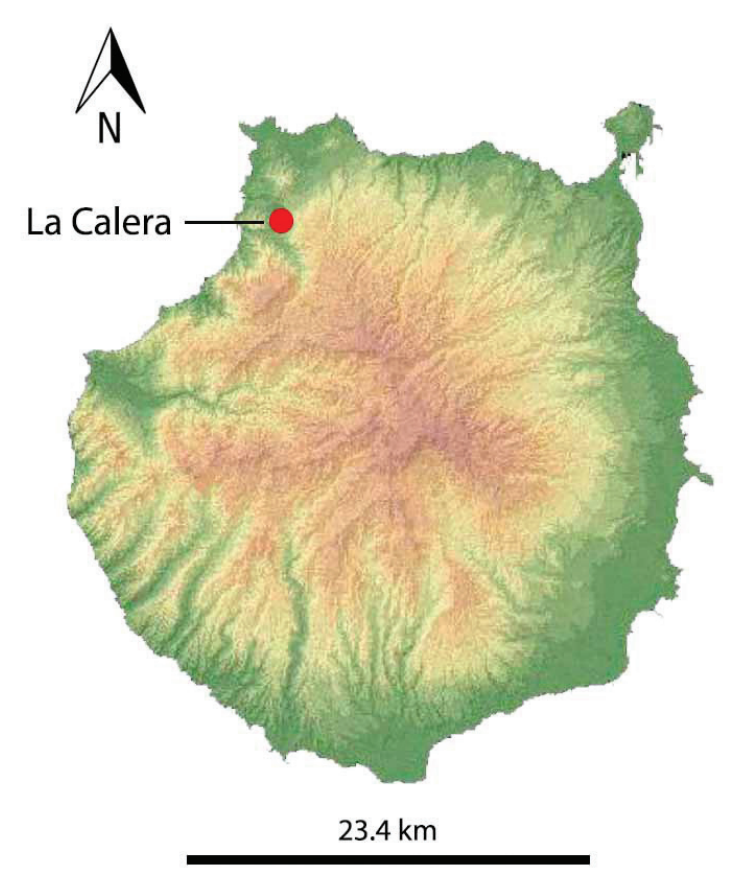

Fig. 2: Location of the Pre-European rotary quern quarry of La Caleta (Agaete, Gran Canaria).

and best preserved rotary quern extraction site. Although previous studies have described the main steps in the manufacturing process, this article focuses on roughing-out the preforms in different stages of work, the tool marks and the extraction tools (picks) found in situ. This analysis also lays down the foundation for a future experimental programme (Rodríguez-Rodríguez and Francisco 2012).

\section{La Calera quern quarry}

La Calera (UTM 433731/3107142) is in the northwest of the island in the Municipality of Agaete (Fig. 2). The site is divided into two main sectors (La Suerte and Las Piletas) along the slope of the Agaete Ravine (Fig. 3).

The La Suerte sector (UTM 433731/3107142, alt. 277 to $292 \mathrm{~m}$ ) is $150 \mathrm{~m}$ long and faces south and west. Although the circular hollows are very well preserved, a section of the quarry face was destroyed by extraction of construction blocks in historical times. These modern workings can easily be recognised by large cubic hollows.

The older surviving quern extractions in other areas are characterised by less regular faces and by a large amount of tuff working debris accumulated at the foot of the quarry faces. The debris comprises stone flakes of different width and size. This waste served in one area to build a working platform held by a stone wall. Basalt picks in various states of use, often fragmented or in the form of flakes, are frequent finds as these tools often broke and were repaired during use. Finds also include abandoned cylinders in different stages of manufacture.

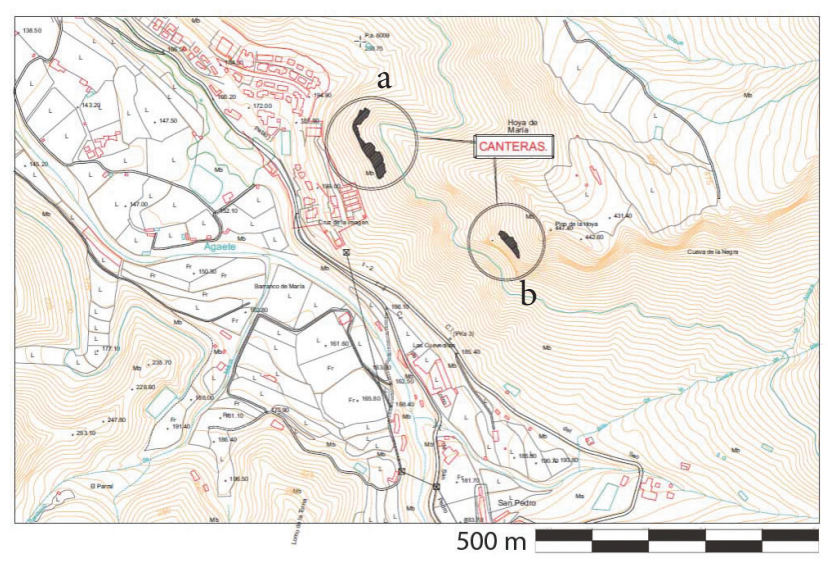

Fig. 3: Map of the two sectors of the Caleta quarry: a) La Suerte and b) Las Piletas.

The rock face of the second sector, Las Piletas (UTM 434973/3106982, alt. 357 to $367 \mathrm{~m}$ ), is $78 \mathrm{~m}$ long. Although the number of extractions is significantly lower, quarrying in certain of its sectors was very intense resulting in large overhangs of the outcrop.

Quarrying in both sectors significantly modified the original form of the hillside. The boundaries of the working areas are marked by clear cuttings several metres deep into the hillside's original natural face. In some areas the working area is over eight metres deep. Workings in two zones were pursued underground forming caves. The extractions are located not only on the faces, but on the floor and along the ceilings. Quarrying was therefore intense and aimed at producing a surplus of products. Elsewhere, beyond of these areas, there are occasional isolated extractions.

From the geological standpoint, the Calera quarry forms part of a strombolian structure eroded in the Middle Pleistocene (Rodríguez-Rodríguez et al. 2006). It is specifically linked to the geological processes of the Post Roque Nublo magmatic cycle (Balcelss et al. 1990). This area of the ravine contains a large accumulation of pyroclastic material as it was a volcanic cone over $30 \mathrm{~m}$ thick composed essentially of basanitic pyroclasts stratified in several layers.

The petrographic and geochemical analyses of thin sections reveal an altered volcanic tuff with a hypocrystalline, vesicular and porphrytic texture with few fine and medium-grained olivine phenocrystals (Mangas et al. 2008). These contain Fe oxides and hydroxides and, therefore, the crystals are almost imperceptible black-reddish pseudomorphs in a dark glassy mestostatis matrix. Sub-euhedral, creamcoloured, fine-grained augite phenocrystals are also present forming, at times, micro-aggregates. The mestostatis contains rounded, irregular and coalescent voids $<4 \mathrm{~mm}$. Some are filled with volcanic glass and zeolite crystals. In the geochemical analysis, the main elements are basanite with averages of $38.5 \% \mathrm{SiO} 2,2.7 \% \mathrm{Na} 2 \mathrm{O}+\mathrm{K} 2 \mathrm{O}$ and $<5.1 \%$ of volatiles. Fe2O3 (mean 20.6\%) and Y (mean 42 ppm) are also present. The analysis of trace elements, essential for studies of provenance, is currently underway. 

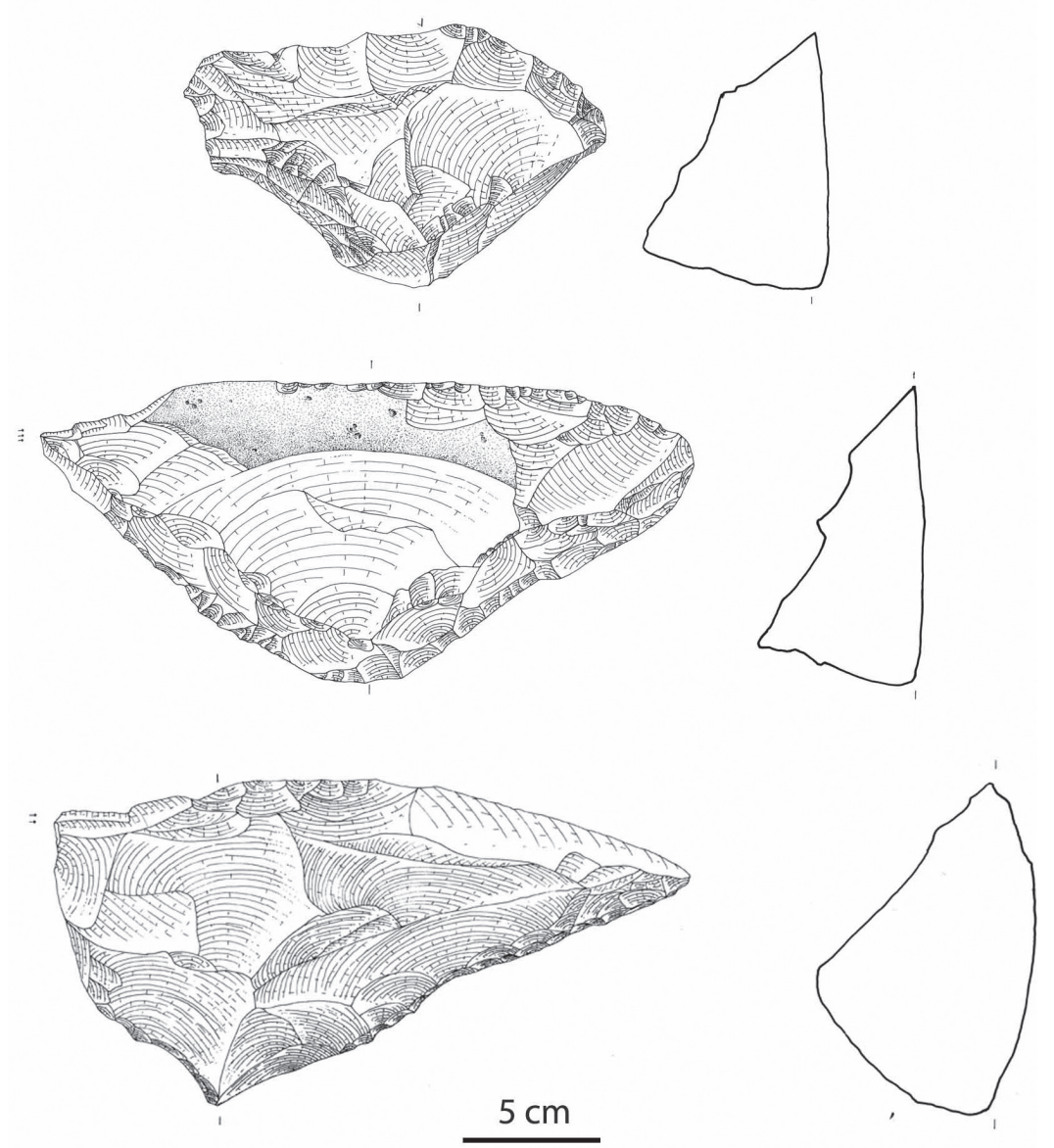

Fig. 4: Basalt picks (extraction tools) from the La Suerte sector of the Caletea quarry (drawing by A. Rodriguez).

\section{Extraction tools: stone picks}

Pre-European Canarians used hard and resistant stone tools to carry out the laborious process of extracting rotary querns from the volcanic tuff rock mass. Based on a number of in situ finds, the extractive tool of choice was the basalt pick. These artefacts, the subject of morphotechnical and functional studies (Rodríguez-Rodríguez and Francisco 2012), take on the form of isosceles triangles with two bevelled or trihedral points (Fig. 4). From the examples recovered among the working debris, it is clear that the quern makers deliberately left crests on these tools to facilitate subsequent maintenance and repair in order to lengthen their life.

The weight of these stone picks suggests hafting and use by means of direct percussion. This technique, as seen through experimentation, would necessitate protection for the quern maker's hands, possibly with some type of leather glove.

The morphotechnical analysis established three types of picks according to the degree of modification undergone from the original triangular shape. Usewear indicate that the stone picks served not only to cut the trench around the cylinder and regularise the quarry face, but to fashion the quern after extraction.

\section{Quarrying: working stages}

\section{Regularising the surface before extraction}

The first step of the rotary quern extraction sequence was to regularise the quarry face by removing unwanted protrusions. This did not require specialised labour, as the basic objective was to obtain a flat working face. This was carried out with picks by means of direct percussion with stokes along $30^{\circ}$ to $40^{\circ}$ angles. This work, observed during the functional analysis, not only affected the points of the picks, but produced wear along the pick's edges. The marks resulting from this preliminary phase are visible on certain quarry faces. The consist of fluted patterns of diagonal lines (Fig. 5).

\section{Extracting the cylinder}

Once the quarry face was regularised, the circumference of the future quern was traced. From the measurement of hundreds of extractions, the preforms were more or less standardised with an average diameter of $39.1 \mathrm{~cm}$. No specific means to sketch the circumference has been identified. It is possible to imagine that a simple implement, 


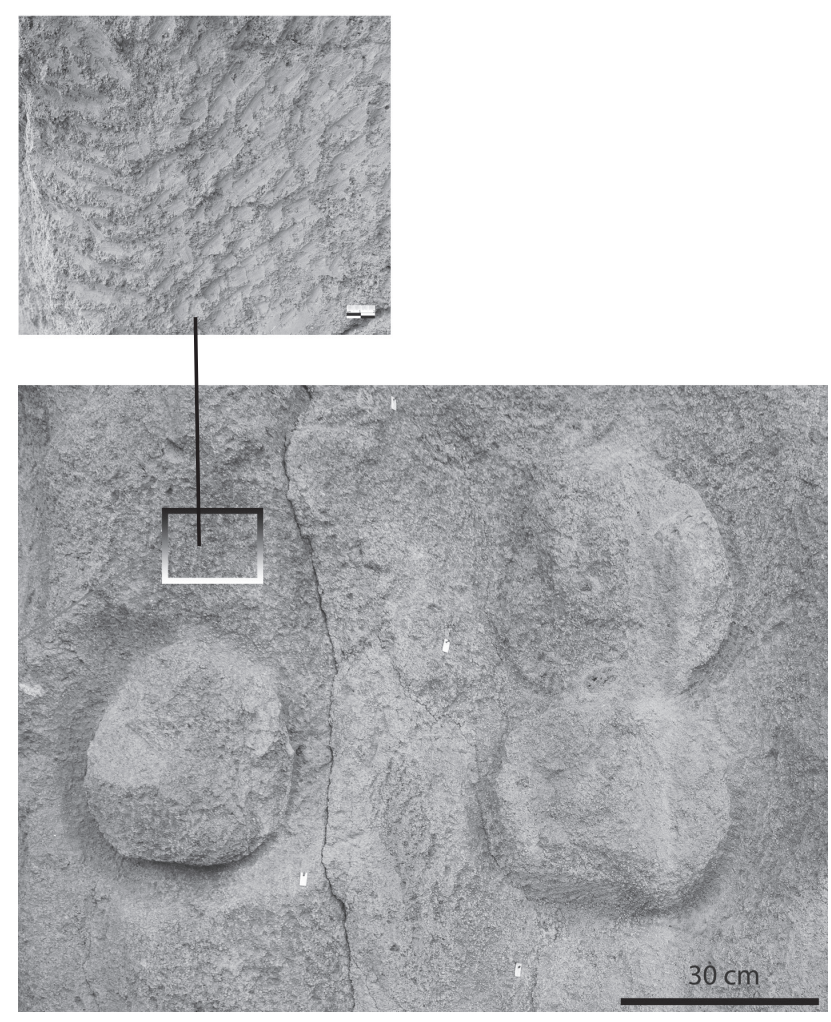

Fig. 5: Group of cylindrical extractions on a vertical plane. The diagonal fluted tool marks are interpreted as regularisation of the quarry surface prior to cylinder extraction (photograph by Y. Naranjo).

such as a piece of charcoal attached to a cord or a string the length of the radius served to trace the circumference. In some cases it is possible to observe a light pecking of the circumference, a sort of a guide for the extraction process.

A circular trench or channel was then cut with a stone pick around the cylinder. The measurement of the width and depth of 70 such trenches indicates that their dimensions ranged, in general, from 8 to $10 \mathrm{~cm}$ in width. Yet the width could vary depending on the conditions of the rock face and the choice of the area of extraction such as along the edge of the outcrop.

Different strategies were applied to cut the trench depending on the hardness of the rock. In some cases, evidence of consecutive pecking has been identified. The marks left by this process, at times still visible at the base of certain trenches, are small pecks with a conical or pyramidal cross-section. At this initial stage, the angle of the pick (direct percussion) was almost perpendicular to that of the rock surface. The angle became progressively more pronounced as the trench deepened. In certain shallower channels, the pick struck the stone diagonally (Fig. 6). At this stage of extraction, the point of the stone pick suffered considerably from wear and often broke.

It is worth noting that the pick was a multifunctional tool as it also served as an abrader to rub the base of the trench and remove the irregularities resulting from the linear pecking.

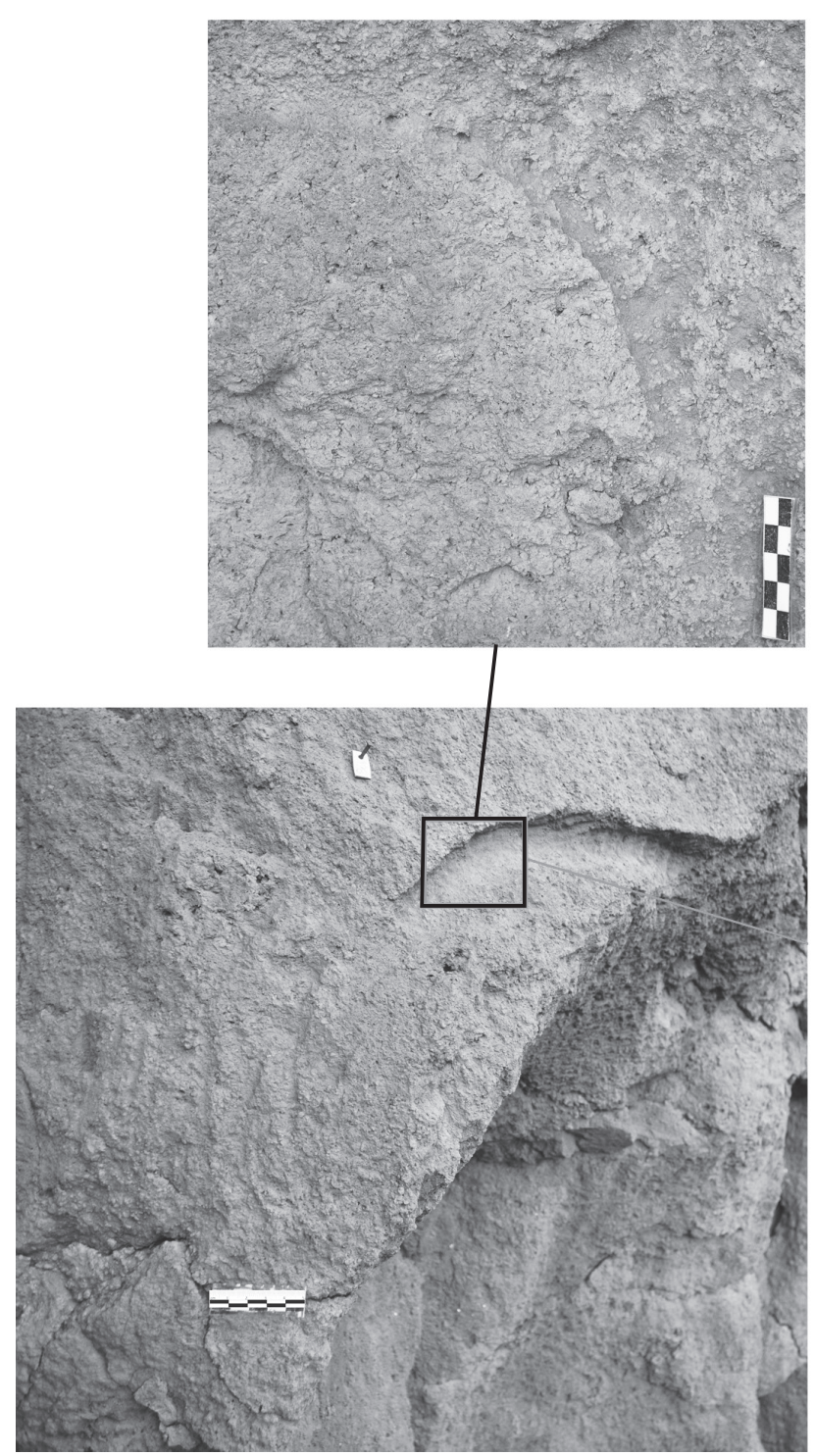

Fig. 6: Marks left during quern extraction on a vertical plane (photograph by Y. Naranjo).

As the trench deepened, the use of direct percussion required greater skill, as any error might break the edge of the cylinder. For this reason, at this stage, it is possible that the picks were stuck with another tools by means of indirect percussion. Although no clear evidence of this has been observed on the rock faces, several picks display marks (pecking, micro-fractures, abrasion and linear accidents) on their sides and base, suggesting they may have served as platforms for indirect percussion. Yet since these marks are rare, the use of triangular picks as chisels for indirect percussion remains hypothetical.

There is also no evidence of stone hammers or wooden mallets serving to strike these 'chisels'. In any case, at this stage, the picks attacked the rock face at an angle of $90^{\circ}$, with an inclination becoming steadily more acute as the trench deepened until it reached the depth of about $20 \mathrm{~cm}$. The total depth of the trench is calculated by adding the average depth of $10 \mathrm{~cm}$ beyond the base of the extracted 


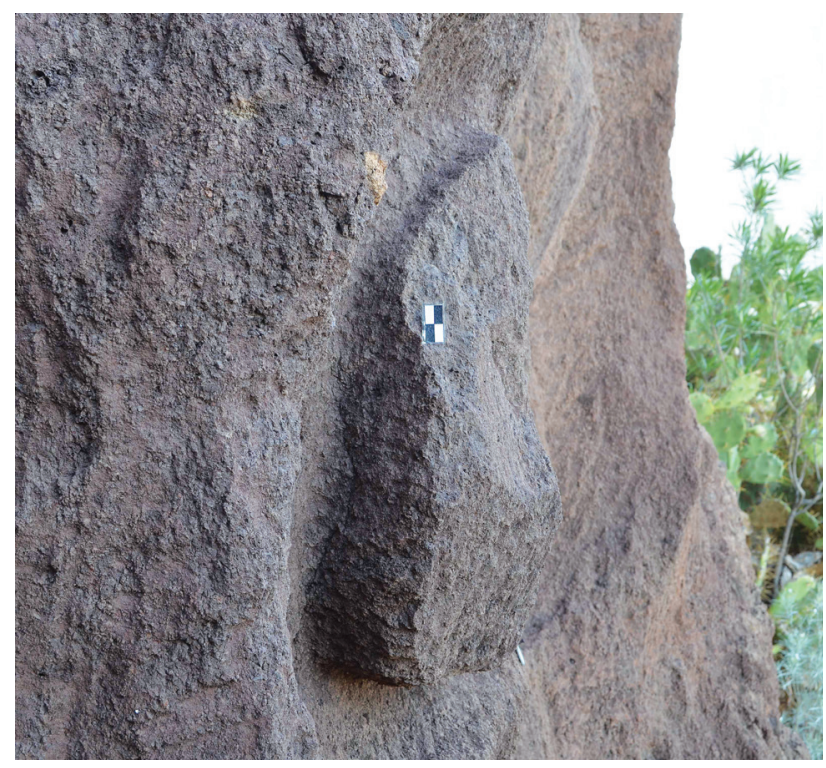

Fig. 7: Detail indicating the depth of a trench cut around the cylindrical roughout (photograph by Y. Naranjo).

cylinder and to the average thickness $(11 \mathrm{~cm})$ of the abandoned roughouts collected at the foot of the quarry face (Fig. 7).

\section{Carving an access to the base of the roughout}

When the trench attained the depth of about $20 \mathrm{~cm}$, the roughout stood out along the vertical quarry face and was ready to be detached from the bedrock. Yet at this stage the quern maker was often obliged to carve a sort of wide "ramp" along the periphery of the trench following an angle of about $45^{\circ}$ so as to facilitate an access to the base of the roughout. Several of these features are visible in the Suerte sector (Fig. 8). In $90 \%$ of the cases, these "ramps" were $40 \mathrm{~cm}(\max )$ wide and placed along the upper part of the cylinder.

This action produced multiple fluted marks suggesting the 'ramp' was cut with a hard tool most likely by means of direct percussion. At this stage it was not likely that the roughout could be damaged by an unfortunate blow as the impacts gradually became less vigorous when approaching the edge of the roughout.

\section{Splitting the roughout from bedrock}

It is not known if the splitting of the roughout was undertaken directly with a pick or indirectly combining the pick with other stone or wooden tools. In any case, there is no indication of the use of wedges set in wedge holes, the most common technique known in Europe since at least Roman times.

In some cases the roughout could have been detached by means of pressure applied with a wooden lever. The use of a lever at this stage of the operational sequence cannot be confirmed as it leaves no characteristic marks. Another option is that the stone picks themselves could have served for this task. Techno-functional studies, for example, have recorded marks not only on their points but also on the crests between them. It is therefore possible that these convex or straight parts of the pick may have served to split the roughout by direct or indirect percussion. This technique allowed the force of the impact to propagate more evenly around the perimeter. Broken roughouts preserved in the quarry indicate that accidents occurred during splitting.

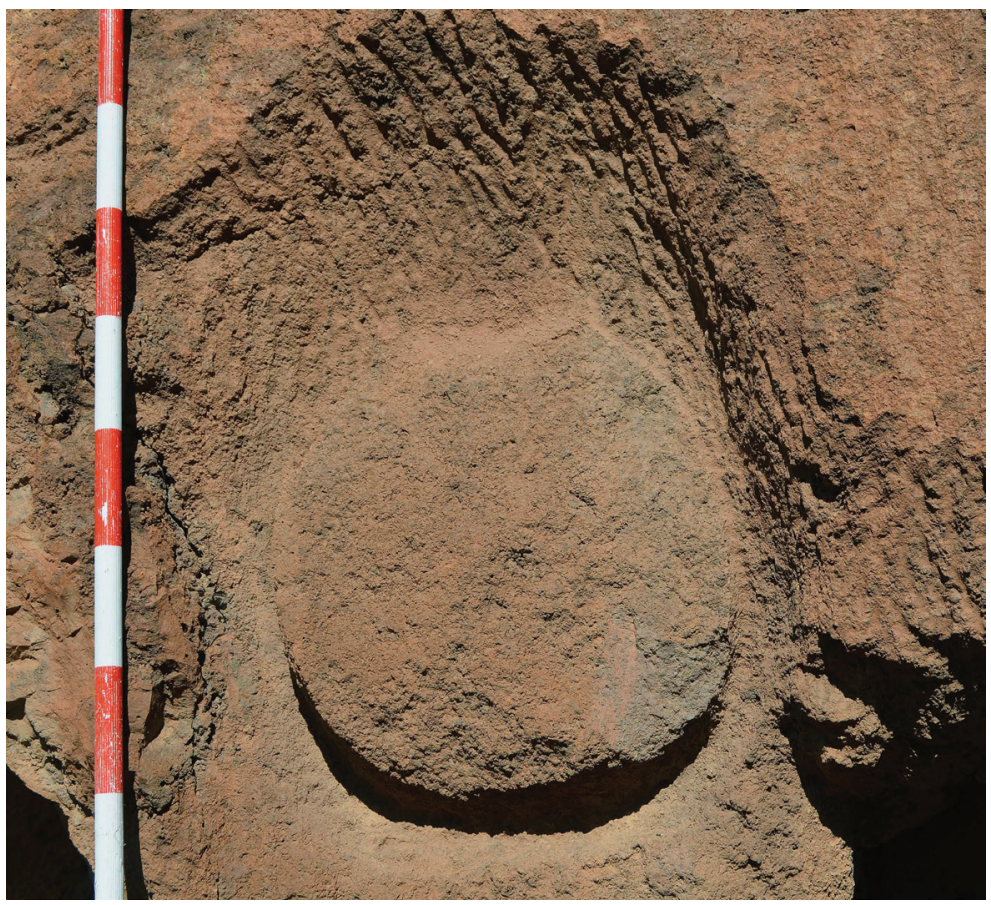

Fig. 8: Detail of an extraction on a vertical plane. The carving of a sort of "ramp" above the trench facilitated access to the base of the the cylinder to split it from the bedrock (photograph by Y. Naranjo). 

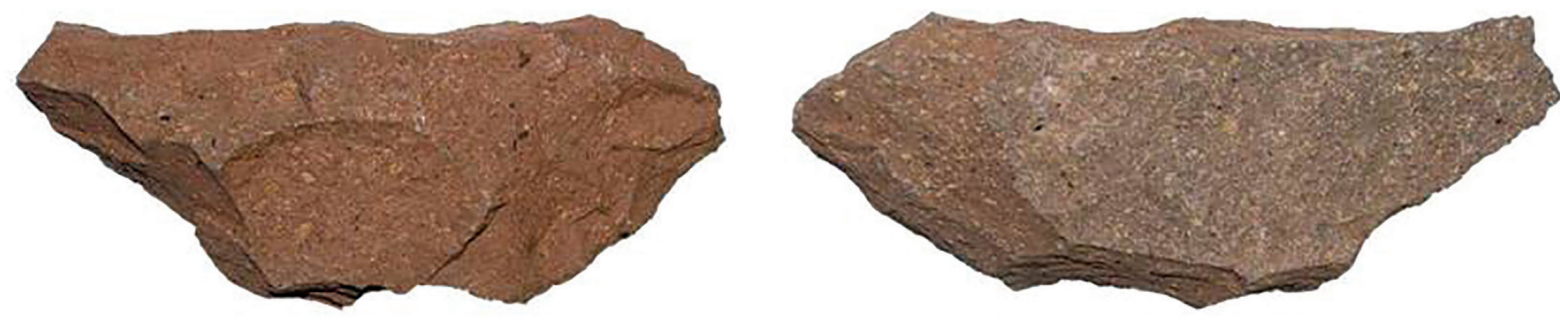

$5 \mathrm{~cm}$

Fig. 9: Examples of small tools from the Suerte quarry (photograph by Y. Naranjo).

\section{Fashioning rotary querns}

The cylindrical roughout detached from the bedrock presented one more or less smooth surface corresponding to the original quarry face and another irregular, slightly convex, surface corresponding to the splitting "plane". At this stage, both surfaces of the roughout had to be regularised. Previous research regarding this phase of work (Rodríguez-Rodríguez 2009) indicates that the roughout was fashioned either by direct percussion with a hammerstone, or by indirect percussion with a dihedral-bevelled stone pick. The picks at this stage were probably smaller than the extraction picks, easier to handle and less likely to fracture the quern (Fig. 9).

Continuous groups of pecking marks, in the form of channels and fluting, are observed on certain roughouts. These marks are the result of direct percussion at an acute angle to equalise the edges of the stones. This stage of the process reduced the roughout's diameter.

Subsequently, a combination of techniques was employed to smoothen the most irregular areas of the quern surface. First they were pounded by direct percussion using a rounded hammer. This action is evidenced by partially fractured querns. There are also marks indicating the use of smaller picks. The querns were subsequently smoothed by abraders made of coarse sandstone. At this stage, to accelerate the process, other means of abrasion, such as sand mixed with water, may also have been used to regularise the grinding surfaces.

\section{Cutting the eye}

Another important task in the final stage of the manufacture of the querns was cutting the central eye. This was a critical operation due to the high risk of fracture. The eye, in fact, may have been cut prior to regularising the grinding surfaces so as to avoid working in vain.

The tool to cut the eye was narrow and light, like examples found at the foot of the Suerte quarry. The irregular surfaces were smoothed by abraders. As observed in the morphological study of rotary querns from other sites of the island, cutting the eye was carried out simultaneously from both surfaces. After completion, the inside of the orifice was smoothed with an abrader until it lost its original bi-conical section and became cylindrical. Yet certain broken examples recovered at sites point to carving the eye from a single face. This second procedure required great precision while offering little guarantee of success and therefore was probably less frequent. In any case, this final stage is not well represented among quarry debris as the querns that survived the cutting of the eye were transferred to their place of use.

\section{Conclusions}

The study of the Calera quarry allows us, by means of the identification of the different tools marks corresponding to each stage of work, to reconstruct the operational sequence of ancient rotary quern production. This task, requiring special skills and experience, was particularly remarkable as the indigenous Canarians did not possess metal tools. Although it has not been possible to equate specific tools to each stage, the different types of use-wear on the picks can be linked to specific stages. In any case, a solid foundation for a future experimental programme is now in place.

The evidence gleaned from the large number of extractions in both sectors of the quarry, in addition to the modifications of the lava outcrop's natural shape, suggest a vast and intense production, making La Calera the largest quern quarry currently recorded in Gran Canaria. Exploiting this outcrop required the labour of a large group of specialised workers who may have enjoyed a specific status within society. Although it is difficult to determine how access to these production facilities was regulated, provenance studies currently being carried out will identify quern distribution patterns that can serve as comparison with the distribution of other abiotic elements. In any case, the data obtained in the quern quarries constitute further evidence of the complex social patterns on the Island of Gran Canaria in Pre-Hispanic times. 


\section{Acknowledgements}

This paper was supported by project HAR201783205-P funded by the Spanish Ministerio de Economía y Competitividad. Yurena Naranjo benefited of a FPI grant funded by the same institution.

\section{Bibliography}

Balcelss, R., Barrera, J. L., Gómez, S., de Aja, J. A. And Ruiz García, M. T. (1990). Mapa Geológico de España, Instituto Tecnológico Geominero de España. Madrid.

GaLVÁN SANTOS, B. (1998). Industria lítica: tallada y pulimentada. Materiales de molturación. In: T. García (ed.). Patrimonio Histórico de Canarias. Gran Canaria, Santa Cruz de Tenerife: 58-61.

González Quintero, P., Moreno Benítez, M. A. AND Jiménez MedinA, A. M. (2009). El yacimiento arqueológico de La Cerera. Un modelo de ocupación en la isla de Gran Canaria. Cabildo de Gran Canaria. Las Palmas de Gran Canaria.

Mangas Viñuela, J., Rodríguez-Rodríguez, A.C., Francisco Ortega, I. And Martín Rodríguez, E. (2008). Canteras aborígenes de molinos de mano en la isla de Gran Canaria (España): caracterización petrológica de tobas de lapilli. Geo-Temas, 10: 1301-04.

Rodríguez-Rodríguez, A. C. (2009). La gestión de los recursos líticos. In: D. BecERra Romero (ed.). El yacimiento arqueológico de La Cerera. Un modelo de ocupación de la isla de Gran Canaria. Cabildo de Gran Canaria. Las Palmas de Gran Canaria: 205-75.

Rodríguez-Rodríguez, A. C. AND Galindo, A. (2004). El aprovechamiento de los recursos líticos en un poblado costero de la isla de Gran Canaria. Las industrias líticas del poblado de El Burrero (Ingenio). Tabona, 13: 143-65.

Rodríguez-Rodríguez, A.C., Martín Rodríguez, E., Mangas Viñuela, J., González Marrero, $\mathbf{M}^{\mathrm{a}}$. C., Buxeda and Garrigós, J. (2006). La explotación de los recursos líticos en la isla de Gran Canaria.
Hacia la reconstrucción de las relaciones sociales de producción en época preeuropea y colonial. In: G. Martínez, A. Morgado and J.A. Afonso (eds). Sociedades prehistóricas, recursos abióticos y territorio. Fundación Ubn al-Jatib de Estudios de Cooperación Cultural. Granada: 367-91.

Rodríguez-Rodríguez, A.C., Martín Rodríguez, E., Mangas Viñuela, J., and Francisco Ortega, I. (2007). Las canteras de molinos de mano de la isla de Gran Canaria. Anatomía de unos centros de producción singulares. Tabona, 15: 115-41.

Rodríguez-Rodríguez, A. C., Martín Rodríguez, E., Mangas Viñuela, J. and Francisco Ortega, I. (2008). Canteras de molinos de mano de los antiguos canarios. In: F. Morales Padrón (coord.). XVII Coloquio de Historia Canario-Americana. Las Palmas de Gran Canaria: 453-74.

Rodríguez-Rodríguez, A.C., Mangas Viñuela, J., Buxeda i Garrigós, J., Martín Rodríguez, E., and Francisco Ortega, I. (2010). La explotación de las canteras de molinos de mano rotatorios en la Gran Canaria preeuropea. In: S. Domínguez-Bella, J. Ramos Muñoz, J. M. Gutiérrez López AND M. PÉrez Rodríguez (eds). Minerales y rocas en las sociedades de la prehistoria. Cádiz: 371-80.

Rodríguez-RodrígueZ, A.C. AND Francisco, M ${ }^{\mathrm{a}}$ I. (2012). Estudio de los picos tallados de la época preeuropea de Gran Canaria. Un ejemplo de especialización en el trabajo a partir de las evidencias recuperadas en la cantera de molinos de Montaña Quemada. Complutum, 23.1: 77-97.

Rodríguez-Rodríguez, A.C., Morales Mateos, J., del-Pino-Curbelo, M., Naranjo Mayor, Y., Martín Rodríguez, E. and González Marrero, M.C. (2012). Espacios de producción especializada, Excedentes y estratificación social en la Gran Canaria Pre-europea. Tabona, 19: 101-23.

Serra Ráfols, E. and Diego Cuscoy, L. (1950). De arqueología canaria. Los molinos de mano. Revista de Historia XVI, 92: 234-97. 